\title{
W. B. Yeats's Robartes-Aherne Writings. Featuring the Making of His "Stories of Michael Robartes and His Friends", Wayne K. Chapman (ed.)
}

\section{Seán Golden}

\section{(2) OpenEdition} Journals

Édition électronique

URL : https://journals.openedition.org/etudesirlandaises/7326

DOI : $10.4000 /$ etudesirlandaises.7326

ISSN : 2259-8863

Éditeur

Presses universitaires de Caen

Édition imprimée

Date de publication : 14 novembre 2019

Pagination : 137-138

ISBN : 978-2-84133-945-7

ISSN : 0183-973X

Référence électronique

Seán Golden, «W. B. Yeats's Robartes-Aherne Writings. Featuring the Making of His "Stories of Michael Robartes and His Friends", Wayne K. Chapman (ed.) ", Études irlandaises [En ligne], 44-1 | 2019, mis en ligne le 14 novembre 2019, consulté le 21 novembre 2022. URL : http://journals.openedition.org/ etudesirlandaises/7326 ; DOI : https://doi.org/10.4000/etudesirlandaises.7326

Creative Commons - Attribution - Pas d'Utilisation Commerciale - Partage dans les Mêmes Conditions 4.0 International - CC BY-NC-SA 4.0

https://creativecommons.org/licenses/by-nc-sa/4.0/ 


\section{COMPTES RENDUS}

\section{BOOK REVIEWS}

\section{W. B. Yeats's Robartes-Aherne Writings. Featuring the Making of His "Stories of Michael Robartes and His Friends", Wayne K. Chapman (ed.), London, Bloomsbury Academic (Modernist Archives), 2018, 372 p.}

Wayne K. Chapman has published "the first genetically conceived, chronologically arranged edition" of the works Yeats wrote around the characters of Michael Robartes and Owen Aherne (and sometimes, his brother John) "in both published and unpublished states" (introduction, p. xviii). The book forms part of Bloomsbury Academic's Modernist Archives Series, dedicated to "archival excavation and thick contextualization" of literary modernism. It is certainly a feat of erudition, tracking down manuscript material at the British Library and libraries at the universities of Harvard, Southern Illinois, SUNY Buffalo and Emory, as well as the National Library of Ireland.

The study is divided into five sections. The first deals with the early appearance of Robartes and Aherne in the Secret Rose triptych: Rosa Alchemica (1896), The Tables of the Law (1896), The Adoration of the Magi (1897). The second traces the "resurrection" of Robartes and Aherne from 1917-1920 in unpublished manuscript material ("The Discoveries of Michael Robartes", "Anglo-Ireland: A Conversation”, "Appendix by Michael Robartes"). The third examines an explosion of creative work from 1919-1925 in The Wild Swans at Coole and Michael Robartes and the Dancer, in "notes" for Four Plays for Dancers and in inventions and extracts for the first version of $A$ Vision, giving important insights into "The Gift of Harun-Al-Rashid" along the way. The fourth part is devoted to the drafting of Stories of Michael Robartes and his Friends. The final section edits "Michael Robartes Foretells" (a text that Yeats chose not to publish) and "Denise's Story", an inserted addition to Stories of Michael Robartes.

By its very nature, this kind of work prioritises the scholarly apparatus, which precedes the published versions of the material. In each section, prefatory matter accompanied by footnotes sketches out the historical context of the preliminary drafts before presenting facsimiles and transcriptions of the manuscripts and typescripts, also accompanied by notes, and where relevant, the published version. A full appreciation of the scholarship involved requires a constant cross-referencing of the prefatory material with the drafts and the published versions, if not an encyclopaedic knowledge of the primary material in addition to the secondary literature on the subject. A prior and studious rereading of the corresponding published versions would be a handy preparation for the narrative arc Chapman traces.

The result of this genetic criticism is a fascinating trajectory of the RobartesAherne characters, replete with biographical information on Yeats and commentary 
on their relevance for the later poems and both versions of $A$ Vision. A rather "Orientalist" Robartes emerges, to Aherne's national Catholic foil, giving Chapman the opportunity to illustrate the role of humour and self-parody in these texts, in their protagonists' repartee and slagging of the poet himself, and in the wry editorial insertions Yeats made to give credence to his "source" material.

Seán GoLdeN

\section{Marie-Monique Léoutre, Serving France, Ireland and England: Ruvigny, Earl of Galway, 1648-1720, London, Routledge, 2018, 238 p.}

Anyone even vaguely familiar with the history of French Protestant exiles to Ireland in the 1600s will identify their settlement at Portarlington, straddling the borders of counties Laois and Offaly, as the second most important outside Dublin. There, French was used in church services until the 1820s, and the area is proud of this Huguenot heritage. But outside scholarly circles, few if any would recognise the name of Henri de Massue, second marquis de Ruvigny (1648-1720), who had established Portarlington but also rose to become the only Lord Justice of Ireland not born a subject of the English monarch. For a time, he was even the acting head of the Irish colonial administration, if not in title, inter alia enacting the antiCatholic legislation known as the Penal Laws, but because he is mostly referred to as Viscount Galway, his French origins have been somewhat obscured. This is the first full biographical treatment of his career, but also sheds light on inter-state conflict in late $17^{\text {th }}$ and early $18^{\text {th }}$ century Western Europe.

The numbers of French Protestants leaving France swelled dramatically after the revocation of the Edict de Nantes in 1685, but within the context of the age's complex intertwining of religion, politics and economic imperialism, confessional identities were further reinforced and realigned on an international scale. Protestants united behind the messianic figure of William III, the "new David in armour" opposing Louis XIV, and Ruvigny became a leading figure in the Protestant International. His father, who had served both Louis XIII and XIV militarily and diplomatically, had been député général of his co-religionists and thus their representative at court. After several missions he had firmly established himself in the highest spheres of English politics, and by 1685 even been naturalised. Thus prepared for exile, the elder Ruvigny settled permanently in England in 1686, was granted permission to reside at the royal palace in Greenwich, and there established a form of "Huguenot head-quarters". The family became increasingly prominent as natural leaders of the French refugee community, ensuring their spiritual needs were met but also assisting with employment and "networking". Ruvigny père had obtained the use of the church at Greenwich for his co-religionists, who worshipped after the regular Anglican service, but using the English liturgy translated into French, an indication they had conformed. 